\title{
Śmiech angielski po polsku. Problemy humoru w przekładach Charlesa Dickensa
}

Aleksandra Budrewicz-Beratan 
UAPIS Seria XIV 2008

\section{Aleksandra Budrewicz-Beratan}

\section{Śmiech angielski po polsku. Problemy humoru w przekładach Charlesa Dickensa}

$\mathrm{N}$

a pytanie, jak tłumaczyć humor Szekspira, Stanisław Barańczak odpowiedział: „Tak, aby śmieszył"1. Barańczak pisał wprawdzie o dramacie, ale jego uwagi są aktualne również dla pozostałych rodzajów literackich. W toczonym od lat sporze - tłumaczyć wiernie czy nie - autor jasno opowiada się za prawem tłumacza do częściowej swobody, by przetłumaczony dowcip się udał, byśmy się śmieli, czytając utwór lub oglądając jego adaptację w teatrze ${ }^{2}$. O korzyściach płynących z takiej zgody - krytyków, czytelników, widzów - na pewien zakres swobody dla tłumacza przekonują znakomite przekłady dramatów Williama Szekspira pióra Barańczaka. Ze wszystkich polskich tłumaczeń szeroko obecne są na polskiej scenie teatralnej ostatnich lat i tam „sprawdzają się" najlepiej. Problematyka przekładu prozy, zwłaszcza humoru i satyry, jest równie frapująca i równie złożona ${ }^{3}$, o czym przekonują liczne prace krytyczne, podejmujące próby naukowych objaśnień, na czym polega i czy wciąż nas śmieszy humor w powieściach obcojęzycznych, przetłumaczonych na język polski ${ }^{4}$.

Przedmiotem zainteresowania rzadko jednak bywają polskie tłumaczenia prozy Charlesa Dickensa ${ }^{5}$. To zaskakujące, bo jest to jeden z najpopularniejszych pisarzy an-

\footnotetext{
${ }^{1}$ S. Barańczak, Jak thumaczyć humor Szekspira?, w: idem, Ocalone w thumaczeniu. Szkice o warsztacie thumacza poezji, Kraków 2004, s. 234.

2 Ibidem, s. 248.

${ }^{3}$ Zob. S. Bassnett, Translation Studies, London, New York 2004, p. 110-119.

${ }^{4}$ Zob. G. Grzegorczyk, Humor, dyskurs, translacja. W jaki sposób obcośc przejawia się w tlumaczeniu tekstów humorystycznych?, w: Przekładajac nieprzekładalne II, red. O. i W. Kubińscy, Gdańsk 2004, s. 77-89; A. KrawczykŁaskarzewska, Degrees of domestication — Bridget Jones in Polish translations, w: ibidem, s. 303-310.

${ }^{5}$ Dotychczas zajmowała się nimi Janina Kulczycka-Saloni w pracach poświęconych recepcji i przekładom Dickensa w Polsce. Zob. eadem, $Z$ dziejów Dickensa w Polsce: „Emancypantki” a „Bleak House”,
} 
gielskich, należących do kanonu literatury światowej. Niniejszy artykuł ma nadzieję choć w małym stopniu wypełnić tę lukę. Problem polskich tłumaczeń dickensowskiej prozy jest rozległy, dlatego w tej pracy zawężam go do jednego tekstu i jednej postaci - Wilkinsa Micawbera, jednego z bohaterów powieści David Copperfield. Taki wybór podpowiedziały mi anglo- i polskojęzyczne prace krytyczne ${ }^{6}$, w których w kreacji tej wlaśnie postaci jednomyślnie widziano dowody na dickensowski talent humorystyczny. Dodatkowy argument, by przyjrzeć się bliżej temu bohaterowi, znalazłam w polskich i obcojęzycznych zbiorach słownikowych cytatów z literatury pięknej. Przytacza się w nich właśnie wypowiedzi Micawbera: w Skrzydlatych stowach — jedną̧, a w oksfordzkim Dictionary of Quotations dwie ironiczne sekwencje ${ }^{8}$. Obecność tego bohatera w pracach różnojęzycznych, które wyselekcjonowały setki cytatów spośród dziesiątek dzieł literackich i pozaliterackich, świadczy o dużej popularności tej postaci. Z kolei według internetowej encyklopedii Wikipedia, nazwisko „Micawber” funkcjonuje $\mathrm{w}$ świadomości potocznej jako synonim postawy człowieka oczekującego z nadzieją na dobry los?.

Utwór Dawid Copperfield, ósma powieść Charlesa Dickensa, ukazywał się w dwudziestu odcinkach w latach 1849-185010. Jest jedną z najpopularniejszych i najlepszych książek Dickensa. Była ona tłumaczona na wiele języków, przerabiana w celach teatralnych oraz adaptowana do potrzeb młodego czytelnika. Łączy w sobie powagę i humor, przedstawiając sceny okrutne i romantyczne, rodzinne ciepło i jego dotkliwy brak. W Polsce zaczęto tlumaczyć Dickensa około 1840 roku. Przekłady ukazywały się przeważnie dopiero kilka lub kilkanaście lat po ogłoszeniu drukiem oryginału. Pierwszy przeklad Davida Copperfielda opublikowano w roku 1857, jego autorem był Franciszek Salezy Dmochowski ${ }^{11}$. Później ukazały się thumaczenia Wilhelminy Zyndram-Kościałkowskiej (1889), Karoliny Beylin (1922), Cecylii Niewiadomskiej (1927), Teresy Świ-

„Prace Polonistyczne” seria 5, Łódź 1947, s. 3-39; Dickens w Polsce, „Przegląd Humanistyczny” 1970, z. 5, s. 27-40. Ponadto o problemie wczesnej recepcji Dickensa w Polsce pisała Mirosława Kocięcka w artykule $Z$ dziejów recepcji Dickensa w Polsce XIX w. (do r. 1900), „Przegląd Humanistyczny” 1962, nr $6(33)$, s. 149-158.

${ }^{6}$ Zob. R. Dyboski, Sto lat literatury angielskiej, Warszawa 1957, s. 139; G. Saintsbury, The Cambridge History of English Literature, vol. 13: The Nineteenth Century II, Cambridge 1916, p. 327; A. Horsman, The Victorian Novel, Oxford 1990, p. 124.

7 Zob. Skrzydlate stowa. Wielki stounik cytatów polskich i obcych, red. H. Markiewicz, A. Romanowski, Kraków 2007, s. 112.

${ }^{8}$ Zob. The Oxford Dictionary of Quotations, ed. G. Cumberlege, Oxford 1953, p. 174-175.

${ }^{9}$ Zob. http://en.wikipedia.org/wiki/Wilkins_Micawber (stan z 31.10.2008).

10 Zob. hasło David Copperfield w: Oxford Reader's Companion to Dickens, ed. P. Schlicke, Oxford 2000, p. 150 oraz w: The Oxford Companion to English Literature, ed. M. Drabble, Oxford 1985, p. 272-273.

11 Powieść miała tytul Wspomnienia sieroty. Dawid Copperfield i prawdopodobnie była tłumaczeniem $\mathrm{z}$ języka francuskiego. Zob. W. Krajewska, Recepcja literatury angielskiej $w$ Polsce $w$ okresie modernizmu (1887-1918). Informacie, sqdy, przekłady, Wrocław 1972, s. 130, 238. 
derskiej (1928). Oprócz przekładów powstały polskie adaptacje powieści. Jan Dąbrowa opracował powieść Dickensa dla młodzieży ${ }^{12}$, Wanda Peszkowa i Wanda Skarżyńska przygotowały podobne wersje w języku angielskim ${ }^{13}$. Tekst Peszkowej był najprawdopodobniej w dużym stopniu zainspirowany angielską wersją niemieckiej pracy David Copperfield's Youth ${ }^{14}$. Świadczy o tym wiele podobieństw: podział powieści na bardzo krótkie rozdziały, duże uproszczenia fabularne, a przede wszystkim ograniczenie opowieści do wydarzeń z czasów dzieciństwa i wczesnej młodości Dawida, przy czym na końcu pracy pojawia się krótkie streszczenie dalszych losów głównego bohatera. Przeróbką dla młodzieży jest też przekład Niewiadomskiej. Wychowawcze cele takich adaptacji i przeznaczenie ich dla uczniów łatwo dostrzec w eliminacji scen zarówno smutnych, jak i zabawnych. Dickens dla młodzieży polskiej w gruncie rzeczy jest wyprany $z$ humoru.

Wilkinsa Micawbera najprościej można przedstawić jako człowieka o dobrym sercu, wiecznie tonącego w długach. Według jego żony Emmy (co jakiś czas powtarzającej dramatycznie, że nigdy nie opuści męża i mocno w niego wierzy), ma on niepospolite umiejętności, a nieszczęśliwy jest tylko z winy społeczeństwa, które nie umie dostrzec zdolności Micawbera i umiejętnie wykorzystać utalentowanego w wielu dziedzinach człowieka. Kiedy czytelnik ich poznaje, Micawberowie mają czwórkę dzieci (chłopca, dziewczynkę i bliźnięta). W późniejszych partiach powieści Emma spodziewa się kolejnego dziecka, a ojciec rodziny trafia w końcu do więzienia za długi. Na prawach dygresji warto dopowiedzieć, że kreując postać Micawbera, Dickens wzorował ją na własnym ojcu, Johnie, który także naraziwszy rodzinę na dlugi, przebywal jakiś czas w więzieniu ${ }^{15}$. Wlaśnie więzienie przedstawione jest w Davidzie Copperfieldzie w zaskakujący sposób: jako miejsce, gdzie człowiek żyje spokojnie, w przyjacielskiej atmosferze, a jego podstawowe potrzeby są zaspokojone. Do więzienia przeprowadza się także rodzina Micawbera. Żyje się im tam zupetnie nieźle, spokojnie i bezpiecznie.

Po wyjściu z więzienia Micawberowie przeprowadzają się do Cantenbury. Tam Micawber robi interesy z Uriahem Heepem - czlowiekiem niebezpiecznym i podstępnym. Nic zatem dziwnego, że oszukuje on Micawbera, ale w wyniku przeprowadzonego przezeń śledztwa oszustwa Heepa zostają ujawnione, bohater zaś odzyskuje godność i szczęście. Wprawdzie pod koniec powieści trafia ponownie do więzienia, ale tym razem na krótko. W rezultacie rodzina Micawberów decyduje się na emigra-

\footnotetext{
${ }^{12}$ Ch. Dickens, David Copperfield, opr. dla młodzieży J. Dąbrowa, Warszawa 1949.

${ }^{13}$ Idem, David Copperfield's boyhood, skróciła i opr. W. Peszkowa, Warszawa 1952; idem, David Copperfield, ed. by W. Skarżyńska, Warszawa 1966.

${ }^{14}$ Idem, David Copperfield's Youth, Wien-Leipzig 1923.

15 G. Cordery, David Copperfield, w: A Companion to Charles Dickens, ed. D. Paroissien, Malden, Oxford, Victoria 2008, p. 377.
} 
cję do Australiii ${ }^{16}$. Tam żyją szczęśliwie i pracowicie, a Micawber robi karierę jako sędzia pokoju. Tak w największym skrócie przedstawia się historia Micawbera, z którą w jakimś momencie (11 rozdział powieści ${ }^{17}$ ) złączą się losy tytułowego bohatera. Gdy po śmierci matki zmuszony do pracy zarobkowej mały Dawid wynajmie u Micawbera pokój, otworzy nowy i lepszy - przynajmniej na jakiś czas - etap swojego niełatwego życia. Niemały w tym udział będzie miał Micawber-bohater komiczny.

Sposób funkcjonowania komizmu wiążący się z jego postacią w wybranych polskich przekładach Davida Copperfielda ujmę w kilku punktach i opiszę, w jaki sposób teksty prezentują Micawbera: czy tak samo nas w nich śmieszy/bawi, a jeśli tak, to w jaki sposób? Przez zachowanie, przez to, co mówi, czy przez to, jak mówi? Czy w zestawieniu $z$ tekstem oryginału „polski Micawber” traci czy zyskuje na swojej charakterystyczności? Czy wnosi do powieści podobny ładunek humoru?

\section{Micawbera życie (jak) w teatrze}

Micawber to chyba najbardziej mobilna postać w Davidzie Copperfieldzie. Jego powieściowe istnienie przypomina scenę w teatrze, na którą aktorzy wchodzą, odgrywają role i schodzą. Micawbera „wchodzenie na” karty powieści i „schodzenie z nich” odbywa się nieprzerwanie, w linearnym porządku: od rozdziału 11, w którym pojawia się po raz pierwszy, aż do finału powieści, w którym dorosły już Dawid otrzymuje list od Micawbera z Australii. Jeśli bohater przebywa dłużej w jakimś miejscu „poza sceną” (pobyty w Plymouth i Canterbury), jego obecność przypominają/potwierdzają listy, które bohater pisze i wysyła nieustannie do przyjaciół. Kiedy Dawid poznaje Micawbera, opisuje go tak:

spostrzegłem tęgiego, niemłodego mężczyznę w ciemnym surducie, czarnych pantoflach i obcisłych spodniach, $z$ głową szeroką i zupełnie lysą, z ogromną twarzą, którą zwrócił ku mnie. Odzież jego była zbrukana, tylko kołnierz od koszuli wyglądał imponująco biało, w ręku trzymał laskę ozdobną sutymi kutasami, na kamizelce połyskiwał monokl, dla ozdoby, jakem się potem przekonal, przewieszony, gdyż używał go rzadko i nic wcale przez niego nie widzial ${ }^{18}$.

\footnotetext{
${ }^{16}$ Prezentacja Australii jako miejsca emigracji jest rzadkością w twórczości Dickensa. David Copperfield jest pod tym względem wyjątkiem, zwykle bowiem do Australii przymusowo transportowano więźniów. Zob. w tej kwestii hasło Australia w: Oxford Reader's Companion to Dickens, op. cit., p. 27-28.

17 We wcześniejszych partiach powieści pisarz obrazuje dramatyzm życia dziecka: mały półsierota mieszka z matką i nianią Pegotty, ich wspólne życie jest skromne, ale szczęśliwe do czasu, kiedy matka wychodzi ponownie za mąż za Murdstone'a, człowieka zimnego i okrutnego. Jawnie niechętny Dawidowi ojczym wysyła go do szkoły.

${ }^{18}$ K. Dickens, Dzieje, przygody, doświadczenia i zapiski Dawida Copperfielda, juniora rodem z Blunderstone (których nigdy ogłaszać drukiem nie zamierzał), tł. W. Zyndram-Kościałkowska w roku 1889, Warszawa
} 
spostrzegłem tęgiego, niemłodego mężczyznę $\mathrm{w}$ ciemnym surducie, czarnych pończochach i obcisłych spodniach, $\mathrm{z}$ olbrzymią, zupełnie tysą głową, z ogromną twarzą, którą zwrócił do mnie. Odzież jego była zniszczona, ale kołnierz koszuli imponująco sztywny. W ręku trzymał laskę, ozdobioną licznymi chwościkami, a u pasa wisiała mu lornetka, która, jak to później zauważyłem, służyła jedynie do ozdoby ${ }^{19}$.

I found there a stoutish, middle-aged person, in a brown surtout and black tights and shoes, with no more hair upon his head (which was a large one, and very shining) than there is upon an egg, and with a very extensive face, which he turned full upon me. His clothes were shabby, but he had an imposing shirt-collar on. He carried a jaunted sort of a stick, with a large pair of rusty tassels to it; and a quizzing-glass hung outside his coat, - for ornament, I afterwards found, as he very seldom looked through it, and couldn't see anything when he did ${ }^{20}$.

Deskrypcja wyglądu postaci w przywołanych przekładach nie różni się w jakiś szczególnie znaczący sposób. W zestawieniu z oryginałem, pierwszy fragment opisowy zachowuje względnie największy stopień wierności. W obu brakuje jednak trzech fraz, prezentujących bohatera w żartobliwy sposób. Chodzi o porównanie: „with no more hair upon his head than there is upon an egg" oraz epitety: „very shining [head]" i „extensive face". Redukcje tłumaczonego tekstu zmniejszyly jego potencjał śmiechu. Różnice w przekładach są niewielkie, ale znaczące. U Kościałkowskiej Micawber nosi obcisłe spodnie. U Beylin - czarne pończochy i obcisłe spodnie. To, co dla jednej autorki przekładu było rodzajem męskich obcisłych spodni, dla drugiej wyglądało jak pończochy. Realistyczna informacja Dickensa w przekładzie wprowadza niezamierzony element lekkiego komizmu, co nie zmienia znaczenia oryginału. Ale w innym przekładzie słowo „pończochy” tworzy obraz mężczyzny ozdobionego atrybutami żeńskiego stroju. To nie tylko komizm, ale ośmieszenie i zdegradowanie postaci. Takiego efektu angielski autor nie oczekiwał, a angielski czytelnik nie przeżywał. Tu widać, jak przekłady wskutek niedostatecznej znajomości realiów epoki mogą wprowadzać efekty komiczne. Na ilustracji Hablota Knighta Browne'a do pierwszego angielskiego wydania Davida Copperfielda postać Micawbera wydaje się asymetryczna ${ }^{21}$, a dysproporcja mię-

1967, s. 145-146. W dalszej części pracy cytaty z tego wydania będę oznaczać skrótem „W. K.”, z podaniem strony.

${ }^{19}$ Idem, David Copperfield. Powieśc, tt. K. Beylin, Warszawa 1989, s. 147. Cytaty z tego wydania będę oznaczać w pracy skrótem „K. B.”, cyfrą arabską oznaczając strony.

${ }^{20}$ Idem, David Copperfield, Penguin Books, London 1994, p. 137. W dalszej części pracy cytaty z wersji angielskiej powieści pochodzić będę z tego wydania, z podaniem strony. (Wszystkie wyróżnienia w cytatach moje - A. B.-B.).

${ }_{21}$ Zob. http://en.wikipedia.org/wiki/Wilkins_Micawber, loc. cit. 
dzy obszernym tułowiem a nadmiernie szczupłymi nogami przywodzi na myśl modę renesansową. Angielski czytelnik (i rysownik) komizm widział w kontrastach wyglądu postaci. Przekład Kościałkowskiej ten kontrast ujmuje jako niedostosowanie białego kołnierzyka do brudnej odzieży, późniejsze tłumaczenie Beylin oddaje to jako nieprzystawanie sztywnego kołnierzyka do zniszczonego ubrania. Druga tłumaczka pokazuje bohatera $z$ typowym dla jej czasów atrybutem stroju inteligenta czy urzędnika. Lornetka zaś każdemu czytelnikowi przywodzi na myśl przedmiot na tyle duży, że jego zawieszenie przy pasie jest tak zaskakujące, iż zwyczajnie śmieszy. Tu przekład wnosi nadwyżkę komizmu postaci, której w oryginale brak. Rzeczy i przedmioty z biegiem lat zmieniły wygląd, przekład tekstu odległego w czasie wnosi pewien potencjał odczytań komicznych, którego autor lub tlumacze mu współcześni nie widzieli.

Przekład Niewiadomskiej nie docenia czytelniczych walorów konkretyzacyjnych dickensowskiego stylu prezentacji postaci. Całkowicie pomija uteatralizowany sposób wkroczenia na powieściową scenę bohatera, ograniczając narratorską informację do beznamiętnego powiadomienia, iż Dawid poznal „dobrych ludzi, ale obciążonych długami i w ciagglych kłopotach o pieniądze"22.

Jedna z najciekawszych scen, mistrzowsko rozegranych przez Micawbera-aktora, ma miejsce w więzieniu. Tam odwiedza go pierwszy raz Dawid i tak to spotkanie relacjonuje:

Pan Micawber czekał na mnie $\mathrm{u}$ furty i poprowadził mnie do swojej celi, zalewając się gorzkimi łzami. Zaklinał mnie, pamiętam, aby mi smutny los jego pozostał na zawsze upomnieniem, że ten, co posiada rocznego dochodu 20 funtów, może wydać tylko 19 funtów, 19 szylingów i 6 pensów, lecz biada mu, jeśli wydaje 21 . Po czym wręczył mi szylinga na porter, dał kartkę do żony i oddał się wesołości [W. K., s. 154].

Pan Micawber czekał na mnie przy furcie i poprowadził do swej celi, zalewając się gorzkimi łzami. Zaklinał mnie, pamiętam, aby mi smutny los jego pozostał na zawsze upomnieniem, że ten, co posiada rocznego dochodu 20 funtów, może wydać 19 szylingów i 6 pensów, lecz biada mu, jeśli wydaje 21. Potem pożyczył ode mnie szylinga na porter, dał kartkę do żony, otarł łzy, schował chusteczkę do kieszeni i natychmiast się rozweselił [K. B., s. 156].

Mr. Micawber was waiting for me within the gate, and we went up to his room (top story but one), and cried very much. He solemnly conjured me, I remember, to take

22 Ch. Dickens, Dawid Copperfield. Powieść, opr. C. Niewiadomska, Lwów-Warszawa 1927, s. 102 (dalej cyt. ze skrótem „C. N.”, z podaniem strony). 
warning by his fate; and to observe that if a man had twenty pounds a-year for his income, and spent nineteen pounds nineteen shillings and sixpence, he would be happy, but that if he spent twenty pounds one he would be miserable. After which he borrowed a shilling of me for porter, gave me a written order on Mrs. Micawber for the amount, and put away his pocket-handkerchief, and cheered up [p. 145].

Przekład Beylin był, bez wątpienia, inspirowany tłumaczeniem Kościałkowskiej - dowodzi tego uważna lektura obu tomów powieści. W niektórych miejscach różnice wobec poprzedniczki ujawniają głębsze zrozumienie przez Beylin psychologii zachowań kreowanej postaci — komicznej konsekwentnie i w każdym szczególe. Dickensowski humor, podtrzymany przez Beylin, pokazuje mistrzostwo „reżysersko-aktorskie" uwięzionego nieszczęśnika, gdy udzielając chłopcu życiowych rad o potrzebie oszczędzania, za chwilę z (oczekiwaną?) premedytacją je zlekceważy, a wymusiwszy w ten sprytny sposób pieniądze, rozweselony aktor schodzi „ze sceny”... na piwo.

Kościałkowska zniszczyła całkowicie urodę tej żartobliwej i wesołej w gruncie rzeczy sceny, mówiąc z powagą doświadczonego pedagoga, że uwięziony poczciwiec odnalazł receptę na poprawę swego losu i będzie się jej w swoim dalszym życiu trzymał. Pod względem stylowym wprowadzona przez tłumaczkę zmiana kłóci się z oczekiwaniami odbiorcy jakiegoś „podstępu” w finale spotkania, które przygotowują: teatralizacja zachowania bohatera (ekspresywna gestykulacja) oraz życzliwy i wyrozumiały stosunek narratora do uwięzionego poczciwca. Także z psychologicznego punktu widzenia trudno uwierzyć, by nieposiadający żadnych pieniędzy Micawber mógł i chciał je dać Dawidowi, w dodatku na zakup smakowitego trunku. Łatwiej uwierzyć, że było akurat na odwrót. To zasługa stylu Dickensowskiego kreowania postaci, obdarzania ich cechami komizmu, tak by w czytelniczych konkretyzacjach budowały się odpowiednie nastawienia odbiorcze na przeżycie radości, wesołości i śmiechu. W jednej wersji przekładu bohater daje szylinga na piwo, w drugiej zaś tę kwotę pożycza. Biedak wręczający wielkopańskim gestem szylinga to obraz satyryczny; tenże bohater pożyczający pieniądze tuż po nauce praktycznej ekonomii jest lekkoduchem, trzpiotem, osobą niepraktyczną, rozmijającą się z głoszonymi zasadami, ale zarazem kimś sympatycznym, przedstawionym w sposób humorystyczny.

Micaweber-aktor komiczny jeszcze nieraz ujawni swoją sceniczną (teatralnie wyreżyserowaną i starannie zagraną) „moc” zamieniania poważnych życiowo sytuacji w zabawne widowisko. Zadziwiająco często ulega zmiennym nastrojom, łatwo przechodząc z płaczu w radość (podobnie zresztą jego żona: „zemdlała na mój widok, a dla pocieszenia ugotowała grzanego piwa z jajami” - K. B., s. 157). Dwa razy Micawber grozi nawet, że okaleczy się brzytwą. W rozdziale 11 nękany przez wierzycieli dłużnik w rozpaczy chwyta za brzytwę z groźną zapowiedzią samobójstwa, by „w pół godziny potem czyścić starannie buty i wyjść z domu pogwizdując tkliwą lub wesołą piosenkę" [W. K., s. 149]. Tak samo łatwo bohater po dramatyzmie najścia wierzycieli przechodzi 
do porządku dziennego, „pogwizdując piosenkę, z właściwym sobie wyrazem dystynkcji" [K. B., s. 151]. Oba tłumaczenia nie modyfikują myśli oryginału:

Mr. Micawber would be transported with grief and mortification, even to the length (as I was once made aware by a scream from his wife) of making motions at himself with a razor; but within half-an-hour afterwards, he would polish up his shoes with extraordinary pains, and go out, humming a tune with a greater air of gentility than ever [p. 140].

Jeszcze raz samobójczą myśl wypowie Micawber, równie rzęsiście zalewając się przy tym łzami, w rozdziale 17 :

na te straszliwe słowa pani Micawber zarzuciła mężowi ręce na szyję, błagając, aby się uspokoił. Zalał się łzami, co mu nie przeszkodziło zaraz potem łzy otarłszy, zadzwonić na służącego i zamówić nazajutrz na śniadanie półmisek gorącego puddingu z cynadrami i porcję raczków [W. K., s. 239].

na te straszliwe słowa pani Micawber zarzuciła mężowi ręce na szyję, błagając, aby się uspokoił. Zalał się łzami, co mu nie przeszkodziło otrzeć łzy, zadzwonić na służącego i zamówić nazajutrz na śniadanie półmisek potrawy z cynaderek i porcję raków [K. B., s. 245].

At this dreadful hint Mrs. Micawber threw her arms round Mr. Micawber's neck and entreated him to be calm. He wept; but so far recovered, almost immediately, as to ring the bell for the waiter, and bespeak a hot kidney pudding and a plate of shrimps for breakfast in the morning [p. 222].

Nic więc dziwnego, że ekspresywność teatralnych gestów, zachowań sytuacyjnych i języka zaczyna oddziaływać na najbliższe otoczenie Micawbera. To cecha mistrza. Dawid na przykład ze zdziwieniem odkrywa, że nabral micawberowskiej maniery pisania patetycznych i obszernych listów. „Zarażony” teatralnością kapitan Hopkins (na ukłony Wilkinsa odkłania się), współlokator więzienny Micawbera, w humorystycznej, demagogicznej scenie pozyskiwania głosów poparcia dla petycji (autorstwa Micawbera) przyjmuje oratorskie cechy swego „mistrza”: z przejęciem, głośniej i dobitniej niż zazwyczaj, uroczyście i z powagą odczytuje pismo tym więźniom, którzy jeszcze się wahają. Pomysły Micawbera, w większości nieodpowiedzialne i lekkomyślne, tym razem odnoszą skutek. Petycja zostaje rozpatrzona pozytywnie, Micawber - uwolniony $z$ więzienia, wierzyciele - uspokojeni. Zdawałoby się, że pechowy bohater wreszcie odetchnie, dumny z sukcesu (przyjęta petycja), szczęśliwy, bo na wolności. Czy tak się rzeczywiście stanie? Kryterium życiowego prawdopodobieństwa przegrywa - szczęśliwie - z żywiolem Dickensowskiego komizmu. 
Dopóki bohatera trapią finansowe tarapaty, kłopoty i trudne sprawy, dopóty zachowuje się on spontanicznie, zmiennie, nieprzewidywalnie, jak zabawny, chciałoby się rzec, szaleniec. $Z$ wielu scen pokazujących go w taki sposób, wybieram do egzemplifikacji tylko jedną - Micawbera na wesołym spotkaniu z kolegami (rozdział 12), które zostanie za chwilę przerwane wieścią przyniesioną przez Dawida; na wiadomość o zaniepokojonej żonie:

Mr. Micawber was in an alarming state, upon which he immediately burst into tears, and came away with me with his waistcoat full of the heads and tails of shrimps, of which he had been partaking.

- 'Emma, my angel!' cried Mr. Micawber, nunning in to the room; 'what is the matter?'

- 'I never will desert you, Micawber!' she exclaimed.

— 'My life!' said Mr. Micawber, taking her in his arms. 'I am perfectly aware of it.

[...] Ah, this has been a dreadful day! We stand alone now - everything is gone from us!'

Mr. Micauber was so deeply affected by this proof of her devotion [...] that he hung over her in a passionate manner, imploring her to look up, and to be calm. [...] Mr. Micawber pressed my hand, and groaned, and afterwards shed tears [p. 150].

Ta bardzo uteatralniona scena zachowała tę właściwość w obu przekładach, choć z małymi modyfikacjami. W przekladzie Beylin stojący za stołem Micawber dyryguje zaimprowizowanym „chórem” kolegów. Na wieść o niepokoju żony

wybuchnął płaczem i pobiegł za mną w ubraniu poplamionym rakami, które przed chwilą spożywal.

— Emmo, aniele mój! — wołał wbiegając do pokoju. — Co się stało?

— Nigdy cię nie opuszczę, Micawber! - krzyknęła.

— Życie moje! - zawołał biorąc ją w ramiona. — Jestem tego pewien!

[...] Ach, cóż to za okropny dzień! Jesteśmy teraz zupełnie opuszczeni, pozostawieni samym sobie!

[...] pan Micawber wzruszył się tak bardzo, że łzy jego zmieszały się z naszymi [...], uścisnął mi dłoń wylewając wiele łez [K. B., s. 162-163].

W przekładzie Kościałkowskiej Micawber „biesiaduje”, siedząc przy długim stole „wtórując śpiewającym chórem”. W tekście angielskim oraz w tłumaczeniu Beylin Micawber nie wtóruje chórowi, lecz mu przewodniczy (,Micawber was leading the chorus", s. 150), co podkreśla jego zdolności przywódcze (wskazywała na nie choćby omawiana wcześniej scena pisania petycji w więzieniu) oraz chęć wyróżnienia się spośród innych. Gdy dowiedział się o niepokoju żony,

rozpłakał się i wybiegł za mną z surdutem pokrytym odłamkami skorupek raków, które właśnie spożywał. 
- Co ci jest, aniele mój, Emmo! — wołał wpadając do celi.

- Nie opuszczę cię nigdy, nigdy! — wołała rzucając mu się w objęcia żona.

— Święcie ci wierzę, aniele mój! Przekonany o tym jestem. [...] Dzień to był wyjątkowo ciężki. Pozostaliśmy sami, przez wszystkich opuszczeni... [...]

Pan Micawber zdawał się być tak wzruszonym tym wybuchem małżeńskiej wierności, że ściskając żonę błagal, aby się uspokoiła [...], wyrzekal, plakał [W. K., s. 160].

Zacytowane dialogi w przekładzie Kościałkowskiej (także w pozostałych rozdzialach) przez koturnowość zachowań, „wyreżyserowaną” nienaturalność wypowiedzi (wzmacnianą przez nadwyżki emocjonalne) oraz ruch sceniczny obojga aktorów (egzaltacja gestów małżonków) nasuwają skojarzenia z formą libretta ${ }^{23}$. Przekłady zachowują komizm postaci i sytuacji (skorupki na ubraniu są równie ważne co wyznanie uczuć) oraz języka (,wybuch” małżeńskiej wierności, a więc połączenie jednorazowości, spontaniczności z cechą długiego trwania).

Operetkowy wydaje się zwłaszcza Micawber, który w oryginale wielokrotnie śmieszy swoją dostojnością, a czasem sztucznością języka, gestów, zachowań. U Kościałkowskiej te cechy bohatera są jeszcze bardziej uwydatnione, czy nawet przerysowane, przez co postać ta, wciąż śmiesząc, każe też zupełnie serio, empatycznie odnieść się do jej życiowych problemów.

Kiedy wydaje się, że nareszcie życie Micawberów zaczyna się uspokajać i porządkować, a zachowanie głowy domu — zmieniać się:

Mr. and Mrs. Micawber were so used to their old difficulties, I think, that they felt quite shipwrecked when they came to consider that they were released from them. All their elasticity was departed [p. 150].

Beylin thumaczy to tak:

Micawberowie tak się przyzwyczaili do swoich kłopotów, że bez nich było im markotno. Cała ich żywotność znikła [K. B., s. 163].

To iście angielski humor - martwić się brakiem problemów. Kościałkowska z kolei uprościła ten fragment, ze szkodą dla charakterystyki bohaterów: „tak się przyzwyczaili do biedy, że się nie mogą pogodzić ze zmianą okoliczności” [W. K., s. 160]. Rezygnując z tych elementów żywotności, energii i dynamizmu, tłumaczka pozbawiła Micaw-

${ }^{23}$ Podobnie jest z przekładem Ciężkich czasów Dickensa, pióra Apolla Nałęcza Korzeniowskiego. Partie dialogowe powieści wielokrotnie brzmią jak tekst przygotowany do odśpiewania na scenie. 
berów właściwości najważniejszej w ich „scenicznym” wizerunku, a zarazem źródła, które rodziło żart, dowcip i humor. Komizm języka u Dickensa i w przekładzie Beylin bawił czytelnika i budził sympatię wobec bohatera; w tłumaczeniu Kościałkowskiej mamy suche sprawozdanie bez cienia uśmiechu.

\section{Micawbera zachowanie się przy stole}

Wspomniałam o sposobie istnienia Micawbera w powieści, o jego nieustannym pojawianiu się i znikaniu. Podobnie „pulsacyjnie” funkcjonują w Davidzie Copperfieldzie Micawberowskie przemowy, listy ${ }^{24}$ i przygotowywanie ponczu. Bohater uwielbia wygłaszać mowy, spontaniczne, długie, barwne, pełne metafor i zwrotów emocjonalnych. Micawber jest dumny ze swego talentu oratorskiego, o czym świadczą jego pozawerbalne zachowania towarzyszące wygłaszaniu przemowy. Niektóre tlumaczenia, jak wspomniany przekład Niewiadomskiej czy anonimowe tlumaczenie z roku 1865, opublikowane w „Bibliotece Rodzinnej”, w sporej części eliminują mowy, skracają je lub streszczają w wypowiedziach innych bohaterów, na przykład:

W nadętych i metaforycznych wyrazach, których powtarzać nie będzi e my [wyróżn. A.B.-B.], [Micawber] uwiadomił Traddlesa, że będzie mieszkał w Kantorbery, że Uriah Heep przyjął go za głównego pisarza i wykupił jego weksle ${ }^{25}$.

Takie zabiegi translatorskie, niewątpliwie, znacząco zubażają charakterystykę bohatera, sprawiając, że polski czytelnik śmieje się podczas lektury Davida Copperfielda rzadziej niż angielski. Szkoda, bo kwieciste przemowy Micawbera są humorystyczne i często satyryczne wobec ówczesnej sytuacji w Wielkiej Brytanii. Przekład Niewiadomskiej nadto szczególnie często podkreśla patos wypowiedzi bohatera poprzez dopowiedzenia: „wykrzyknął patetycznie” (s. 139) czy ,jak zwykle był tragiczno-patetyczny” (s. 172). Poniższy przykład jednej z uroczystych przemów Micawbera (rozdział 36) w dwóch wersjach tłumaczeń pokaże charakterystyczne mechanizmy językowe, które kształtują ów patos sceny pożegnania z Dawidem:

- Kochany panie Copperfield! - rozpoczął pan Micawber, wstając z miejsca i kładąc palec do kieszonki kamizelki - towarzyszu mojej młodości, jeśli mogę się tak wyrazić, i ty, przyjacielu mój, szanowny panie

24 Wspomniane tu ulubione zajęcia Micawbera są wielokrotnie omawiane w pracach krytycznoliterackich. Zob. np. G. Storey, David Copperfield. Interweaving Truth and Fiction, Boston 1991 (tu zwłaszcza rozdział szósty, zatytułowany Voices, p. 58-68).

25 [Ch. Dickens, David Copperfield], „Biblioteka Rodzinna. Powieści, zarysy historyczne i podróże, stosowne dla czytelników każdego wieku i stanu”, t. 4, Warszawa 1865, s. 71. 
Traddles, pozwolicie, że w imieniu moim, pani Micawber i mego potomstwa wyrażę gorące i niedwuznaczne wyrazy podziękowania za życzenia i w ten ostatni wieczór starego życia, w przededniu wędrówki, która zmieni nasz byt całkowicie (pan Micawber mówil tak, jak gdyby wędrować mieli o pięćset tysięcy mil) niech mi będzie wolno zwrócić słowa pożegnania do mych przyjaciół $[\ldots]$ chmura rozwiała się wreszcie i bóg światła znowu ukazał swe oblicze [K. B., t. 2, s. 91].

— Kochany Copperfieldzie - podjął pan Micawber powstając z miejsca, oba wielkie palce trzymając założone w kieszonki kamizelki — kochany Copperfieldzie, towarzyszu mej młodości, i ty, wielce szanowny przyjacielu mój, Traddlesie! Pozwólcie, abym w imieniu własnym, tu obecnej żony mej, potomstwa naszego złożył wam najgorętsze podziękowanie za dobre życzenia, jakimi nas obdarzyć raczycie w przeddzień wyjazdu i rozstania - pan Micawber mówil tak, jak gdyby wyjeżdżal za ocean! - Rozpoczynamy nowe życie. U progu nieznanej przyszłości pozwolę sobie zrobić parę pożegnalnych uwag tu obecnym młodym mym przyjaciołom [...], wszystko to dziś minęło, rozpierzchło się jak chmury pod zwycięskiego słońca promieniem [W. K., s. 487].

'My dear Copperfield,' said Mr. Micawber, rising with one of his thumbs in each of his waistcoat pockets, 'the companion of my youth: if I may be allowed the expression - and my esteemed friend Traddles: if I may be permitted to call him so - will allow me, on the part of Mrs. Micawber, myself, and our offspring, to thank them in the warmest and most uncompromising terms for their good wishes. It may be expected that on the eve of a migration which will consign us to a perfectly new existence,' Mr. Micawber spoke as if they were going five hundred thousand miles, 'I should offer a few valedictory remarks to two such friends as I see before me $[. .$.$] the cloud$ has passed from the dreary scene, and the God of Day is once more high upon the mountain tops [p. 439].

Zanim skomentujemy cechy tej wypowiedzi, poddajmy jeszcze oglądowi listy, które bohater wysyła do adresatów - najczęściej do Dawida. Parokrotnie, w wielkim sekrecie przed mężem, ale zdecydowanie w jego stylu, listy pisze też Emma Micawber, zwykle prosząc nadawcę o pomoc i radę. Poniższe cytaty - fragmenty listu do Dawida, w którym autor zwierza się ze swoich, tradycyjnie juz finansowych, kłopotów (rozdzial 49) - zilustrują próbkę micawberowskich zdolności epistolarnych:

Nie zastanawiając się dłużej nad własnymi zdolnościami i zasługami, umiejętnością powstrzymania gromów i kierowaniu palącą błyskawic iskrą, pozwolę sobie zauważyć mimochodem, że najpiękniejsze marzenia 
moje rozwiane zostały, spokój zniszczony, strawiona radość żywota mego, serce zatrute, czoło na zawsze zasępione. Robak się w bujnym zalągł kwiecie, przepełniła się goryczy czara, posiew podcięty u samych korzeni. Im prędzej to się skończy, tym lepiej [W. K., s. 630-631].

Nie powołując się na żadne zdolności, które, być może drzemią w mej naturze, nie ciskając na niczyją głowę gromów ani nie kierując w żadną stronę mściwego płomienia, powiem tylko, że wszystkie moje marzenia się rozwiały, że serce moje nie bije już na właściwym miejscu i że nie mogę wędrować już wśród ludzi z podniesioną głową. Robak zalągł się w kwiecie. Czarę przepełnia gorycz po brzegi. Gad czyha i wkrótce pochwyci swą ofiarę. Im prędzej, tym lepiej [K. B., t. 2, s. 245].

Without more directly referring to any latent ability that may possibly exist on my part, of wielding the thunderbolt, or directing the devouring and avenging flame in any quarter, I may be permitted to observe, in passing, that my brightest visions are for ever dispelled - that my peace is shattered and $m y$ power of enjoyment destroyed - that my heart is no longer in the right place - and that I no more walk erect before my fellow man. The canker is in the flower. The cup is bitter to the brim. The worm is at his work, and will soon dispose of his victim. The sooner the better [p. 573].

Tym, co uderza w przekładzie Kościałkowskiej, jest poetyczność i liryzm, które rozbijają, rozbrajają ładunek komiczny tego fragmentu. Poprzez aluzję do Marii Antoniego Malczewskiego (poematu romantycznego), tłumaczenie to nasyca się estetyką grozy, złowrogich przeczuć i smutku. W oryginale komizm polega na nagromadzeniu potocznych metafor w krótkim fragmencie tekstu (dodajmy, że jest to cecha wszystkich listów Micawbera w analizowanej powieści). Obrazowość i metaforyka użyte w nadmiarze sprawiają, że Micawber mówiący górnolotnym i napuszonym stylem jest bliski tragicznemu patosowi, co ostro kontrastuje z jego pozycją społeczną, z pospolitym zachowaniem i codziennym, przyziemnym charakterem dręczących go problemów. Wzniosłości stylu nie odpowiada osoba mówcy. Kościałkowska (przypomnijmy daty jej urodzenia i śmierci: 1844-1926) nie bardzo śmiała się ze sposobu mówienia, gestów czy ubioru dickensowskich postaci, bo kultura dziewiętnastowieczna była jej przecież bardzo bliska. Dla niej była to codzienność. Dla tłumaczy późniejszych już nie. Ten sam list w przekładzie Niewiadomskiej został zaledwie streszczony i zacytowany:

malował w słowach tragicznych swój nastrój. Pozbawiony „pogody i spokoju ducha”, z „sercem zatrutym”, nie śmiąc „podnieść czola wobec swych bliźnich”, ani „patrzeć w przyszłość”, pragnie wychylić do dna „gorzki kielich” i „spocząć w grobie”, gdzie „robak zgryzoty ustąpi swej 
roli łagodniejszemu robakowi ciała". Żegnając świat ten jednak, pożąda raz ostatni „zerwać się z łańcucha” i rzucić okiem w lepszą niegdyś przeszłość [C. N., s. 215-216].

Tłumaczka poprzez dobór cytatów z Dickensa kieruje uwag̨ czytelnika i estetyką odbioru. Redukując tekst Dickensa, zagęściła partie, które charakteryzują bohatera jako bufona posługującego się kwiecistym, napuszonym stylem. Czytelnik angielski oraz polski w trakcie lektury pełnego przekładu nie tylko bawią się parodystycznym naśladowaniem zwyczajów oratorskich i odczuwają wyższość wobec ośmieszanego mówcy. Smakują również urodę fraz i okresów krasomówczych, ich rytmikę i ciągi obrazów. Czytelnik okrojonego dla młodzieży przekładu polskiego obcuje z tekstem nie tak zabawnym, jego uwaga jest kierowana na wady stylu, których się ma wystrzegać. Nauczycielka (tłumaczka) dawkuje mu porcje śmiechu, a i tę namiastkę Dickensa przepuszcza przez filtr dydaktyki. Podobną praktykę stosuje Niewiadomska jeszcze parokrotnie, na przykład w kulminacyjnej scenie pojedynku Micawbera i Heepa (rozdział 52). Micawber odczytuje obszerną przemowę, w której przedstawia rezultaty swojego prywatnego śledztwa i udowadnia nikczemność Heepa. Dla fabuły Copperfielda to jedna z najważniejszych scen powieści, w której zło zostaje ukarane, Heep trafia do więzienia, a Micawber czyni przed zebranymi rachunek sumienia ${ }^{26}$.

Dzięki metodzie stosowania mowy niezależnej w miejsce listów i przemów Niewiadomskiej udało się skrócić Davida Copperfielda do zaledwie 245 stron, podczas gdy oryginał ma ich prawie tysiąc, a inne polskie, ,pełne” przekłady mają po około 800 stron. Nie tylko te fragmenty powieści zostały skrócone. Uproszczone zostały także niektóre wątki poboczne. Niewiadomska oraz Jan Dąbrowa w wersji Copperfielda ad usum Delphini zrezygnowali z ważnej i tragicznej w skutkach historii uwiedzenia Emilki przez Steerfortha. U Niewiadomskiej postacie przyjaciół Dawida z dzieciństwa — Emilka i jej narzeczony Ham — są potraktowani jako przykład ludzi z niższej warstwy społecznej, którzy zakładają rodzinę i żyją razem bardzo skromnie, ale szczęśliwie. Rodzina ukazana w sposób sentymentalny jako główny ośrodek zainteresowania i zarazem cel wszelakich ludzkich dążeń i poczynañ ${ }^{27}$ to charakterystyczny dla powieści wiktoriańskiej - którą jest David Copperfield — aspekt realistyczno-obyczajowy. Dickens już od wczesnych powieści ukazywał ideał domu jako miejsca bezpiecznego, radosnego, chroniącego czlowieka przed niełaskawym losem².

\footnotetext{
26 Wydarzenia, jakie następują po omawianej scenie, prowadzą do szczęśliwego - dla większości bohaterów - zakończenia: Micawberowie emigrują do Australii, Dawid żeni się z Agnieszką, Uriah Heep i jego służący Littimer trafiają do więzienia.

${ }^{27}$ Zob. G. Sinko, Postowie, w: Dawid Copperfield, tł. W. Kościałkowska, op. cit., s. 793.

28 Zob. hasło Domesticity w: Oxford Reader's Companion to Dickens, op. cit., p. 189-193. W omawianej powieści Dawid znajduje rodzinne ciepło i bezpieczeństwo właśnie u Micawberów.
} 
Dalej: w przekładzie Niewiadomskiej Steerforth pojawia się, ale do końca pozostaje bohaterem pozytywnym. Pod koniec powieści czytelnicy są poinformowani, że zginął tragicznie podczas silnej burzy. Emilka nie spotyka Steerfortha, wobec czego Ham nie cierpi, kiedy ukochana opuszcza go dla innego. Ham nie ginie tragicznie podczas sztormu, chcąc wielkodusznie ratować tego, kto odebrał mu szczęście. Te wydarzenia mają jednak miejsce w tekście oryginalnym i w innych polskich przekładach. W Copperfieldzie opracowanym dla mtodzieży (liczącym 227 stron, łącznie z ilustracjami) idylla Emilki przerwana jest przez śmierć narzeczonego, który ginie w burzy morskiej razem ze Steerforthem, o czym informuje jedno zdanie pod koniec powieści. Wątku uwiedzenia jednak, w tym tekście dla młodego czytelnika, nie ma (zapewne z powodów wychowawczych), choć są zdania typu:

Tak więc złe skłonności, które za młodu opanowały duszę Uriasza, powodowały nim i później. Z przykrych niezmiernie wypadków w Canterbury nie wyciągnął należytej nauki i zmusił społeczeństwo do użycia środków zapobiegawczych, których w swoim czasie, licząc się z możliwością poprawy, chcieliśmy uniknąć! [C. N., s. 217].

Obecność takich komentarzy podyktowało samo dydaktyczno-wychowawcze przeznaczenie książki i jej potencjalny odbiorca, ale być może także ówczesne warunki polityczne (omawiane wydanie ukazało się w roku 1947).

Względy wychowawcze zapewne spowodowały także, że w obu omawianych wersjach nie pojawia się postać prostytutki Marty Endell ${ }^{29}$, z którą w powieści Dickensa wiążą się wątki: nieszczęścia, próby samobójczej na brzegu rzeki Tamizy, obrazów mrocznych, brudnych i biednych zakątków Londynu, ale także pomocy dla upokorzonej Emilki. W dziewiętnastowiecznej, wiktoriańskiej Anglii prostytucja była „wielkim społecznym złem". Prostytutki przedstawiano w literaturze i sztuce jako kobiety upadłe i grzeszne, ciemne, w opozycji do kobiet jasnych — „aniołów domowych”. Takim jasnym „aniołem" jest w Davidzie Copperfieldzie pełna dobroci i lagodności Agnes Wickfield, wieloletnia przyjaciółka, a w końcu druga żona Dawida. W powieści Marta ukazana jest jako samotna i smutna kobieta, która jednak odnajduje swoje szczęście, emigrując do Australii i wychodząc za mąż za farmera. Marta nie jest przedstawiona jako kobieta, która z własnej winy „upadła” na niski próg drabiny społecznej. Martą się w Davidzie Copperfieldzie nie gardzi, Marcie się współczuje i pomaga. To dzięki niej udaje się znaleźć i uratować Emilkę.

\footnotetext{
${ }^{29}$ Historia Marty wiązała się z projektem Domu dla Bezdomnych Kobiet Urania Cottage (1847-1858), który Dickens, aktywny zwolennik reform społecznych, założył i którym administrował przy współpracy z Angelą Burdett-Coutts. Było to w zamierzeniu miejsce schronienia dla prostytutek i kobiet zamieszanych w przestępstwa. Więcej na ten temat zob. hasło Urania Cottage, w: Oxford Reader's Companion to Dickens, op. cit., p. 590-591. Por. też D. Suchoff, Critical Theory and the Novel. Mass Society and Cultural Criticism in Dickens, Melville, and Kafka, Wisconsin 1994, p. 53.
} 
Językoznawcy, badający zjawisko humoru, twierdzą, że jest to problem szczególnie trudny do analizy, ponieważ tylko częściowo zasadza się on na języku ${ }^{30}$. W dużej części zaś zagadnienie ma charakter pozajęzykowy. Aspekty kulturowe i wielowarstwowość omawianego zjawiska zaznaczają się szczególnie mocno, kiedy podmiotem analizy staje się przekład utworu literackiego. W omówionych tłumaczeniach Davida Copperfielda widać i słychać rozmaite różnice na poziomie stylistycznym tekstu. Polski czytelnik analizowanej powieści Dickensa śmieje się i wzrusza na przemian — dodajmy, na szczęście, bo podobnie reaguje na Copperfielda czytelnik anglojęzyczny.

Analiza porównawcza kilku polskich przekładów Davida Copperfielda dowodzi, że ekwiwalencję humoru Dickensa tłumacze najłatwiej osiągają przy komizmie sytuacji, gdy efekt śmiechu najmniej zależy od subtelności języka. Tu teatralizacja działań pierwszoplanowego bohatera jest dobitnym przykładem. Komizm postaci w przekładzie w większym stopniu zależy od znajomości realiów epoki. Przekłady albo nie są tak zabawne jak oryginał, albo wprowadzają elementy śmiechu tam, gdzie w oryginale są partie neutralne estetycznie. Komizm językowy z powodu silnego związania $z$ macierzystym kontekstem kulturowym oryginału jest najtrudniejszy do przełożenia. Podobnie z wersjami pisanymi dla młodego czytelnika, jak adaptacja Jana Dąbrowy — aspekt humorystyczny dotyczy głównie komizmu sytuacyjnego, rzadziej — komizmu słownego. Z zabawnych sytuacji (na przykład $z$ wiecznego pokrzykiwania charyzmatycznej ciotki Betsey Trotwood na służącą, by pilnowała osłów) latwiej się młodzieży śmiać niż z kwiecistych, napuszonych tyrad Micawbera. Polskie adaptacje omawianej powieści są uproszczone, skrócone i mniej dziewiętnastowieczne: brak w nich bowiem obszernych i fascynujących opisów miast, wsi i krajobrazów dziewiętnastowiecznej Anglii. Realizm powieści Dickensa - a zwłaszcza bogactwo języka i zindywidualizowanie postaci - został w dużej mierze okrojony. Pełne polskie przekłady powieści są dość liczne. W omawianym tłumaczeniu Kościałkowskiej dominuje patos, doniosłość, przez co ładunek humorystyczny jest mniejszy niż w tekście oryginalnym. Przekład Karoliny Beylin, bardziej zrozumiały dla współczesnego czytelnika, przedstawia Micawbera mniej patetycznego, a bardziej zabawnego.

Angielska konwencja towarzyska przewidywała dla gentlemanów skalę ruchów i gestów (tj. pozawerbalnych środków ekspresji) stonowaną i ograniczoną. Micawber jest ruchliwy ponad przewidywania takiej konwencji, a jego ciągłe zmienianie miejsc i pozycji ciała śmieszyło Anglików, ponieważ kontrastowało z wzorem gentlemana. W wersji angielskiej Micawber jest pewnym typem postaci; w polskich przekładach - psychologicznym charakterem. Krytyka anglosaska zwraca uwagę na ruchliwość bohatera, a więc ta cecha musiała ją szczególnie zaskakiwać. Micawber zachowuje się jak

${ }^{30}$ Zob. W. Chłopicki, Humor jako mechanizm pragmatyczny - na przykładzie anglosaskich opowiadań humorystycznych, „Acta Universitatis Nicolai Copernici. Studia Slavica” t. 10, z. 374, Toruń 2005, s. 165. 
bohater komedii dell'arte. Tu humor Dickensa dyskretnie krytykuje naruszenie przyjętych norm i charakteryzuje Micawbera jako kogoś nieautentycznego. Wobec tego Micawber jest bardziej włoskim aktorem niż angielskim gentlemanem. Polskie normy towarzyskie były w tym względzie bardziej liberalne. Sama ruchliwość i gadatliwość Micawbera nie była aż tak śmieszna, dlatego przekłady zawierają narratorskie komentarze, objaśniające patos i nienaturalność. Ale to mniej śmieszy.

Na szczęście jednak polski przekład Davida Copperfielda na przemian bawi i wzrusza czytelników. Chyba jest z Dickensem tak, jak z Szekspirem: każda epoka ma swojego Szekspira i - dodajmy - swojego Dickensa. Od XIX wieku powstają wciąż nowe tłumaczenia dzieł wspomnianych twórców, a ich analiza porównawcza dowodzi wielu istotnych zmian, zarówno w warstwie stylistycznej, jak i semantycznej. Ciekawym zadaniem badawczym byłaby analiza pozostałych polskich przekładów Davida Copperfielda, zwłaszcza wyróżniającego się spośród nich tłumaczenia Teresy Świderskiej. Rozpatrywane pod kątem wybranego zagadnienia czy poszczególnych bohaterów przekłady Dickensa z calą pewnością zasługują na baczniejszą niż dotąd uwagę. „Polski Dickens” bowiem jest zjawiskiem ważnym i wciąż żywym w literaturze polskiej. 